\title{
Mixed-Infection of Papaya Ring Spot Virus and Tomato Leaf Curl New Delhi Virus in Coccinia grandis in India
}

\author{
Siriya Sultana, Buddhadeb Roy and Ang Rinzing Sherpa* \\ Department of Botany, West Bengal State University, Berunanpukuria, Malikapur, North-24 \\ Parganas, Barasat, Kolkata-700126, West Bengal, India \\ *Corresponding author
}

A B S T R A C T

\section{Ke y w o r d s \\ Coccinia grandis, PRSV, \\ ToLCNDV, ACP-ELISA, RT-PCR. \\ Article Info \\ Accepted: \\ 17 June 2017 \\ Available Online: \\ 10 July 2017}

During survey from March 2014 to October 2015, in Barasat, West Bengal, India, incidence of symptoms suggestive of virus infection was observed in Coccinia grandis. Infected plants were showing typical symptoms including leaf curling, crinkled leaves, leaf yellowing and stunted growth. Symptomatic plant samples were tested for the presence of potyvirus and geminivirus. The occurrence of potyviruses was confirmed by ACP-ELISA, RT-PCR and nucleotide analysis of the part of genome. On the other hand, occurrences of geminiviruses were confirmed by southern blot analysis, polymerase chain reaction (PCR) and nucleotide analysis of the part of genome. Sequence analysis showed that the potyvirus from $C$. grandis shares $92 \%$ identity with Papaya ring spot virus (PRSV) isolate at the nucleotide level. The Geminivirus from the $C$. grandis shares $98 \%$ identity with Tomato leaf curl New Delhi virus at the nucleotide level. This is the first evidence of mixed infection of Papaya ring spot virus and Tomato leaf curl New Delhi virus in C. grandis in India.

\section{Introduction}

Natural mixed infections of plant viruses are found frequently all over the world, leading to the variations in symptoms, infectivity, vector transmissibility and economic loss. Mixed infections with potyvirus and geminivirus have been reported in several hosts over a wide geographic area (Martín and Elena, 2009; Verma et al., 2014). The Potyvirus is the largest genus of the family Potyviridae. It contains more than 200 definite and tentative species (Berger et al., 2005) which cause significant losses in agricultural, pasture, horticultural and ornamental plants (Ward and Shukla, 1991). They infect a wide range of monocotyledonous and dicotyledonous plant species and have been found in most parts of the world (Gibbs and Ohshima 2010). Potyvirus distribution is worldwide, they are most prevalent in tropical and subtropical countries (Shukla et al., 1998). On the other hand geminiviruses make up a large, diverse family of plant viruses that infect a broad variety of food and fiber crops and cause significant losses worldwide. The majority of begomoviruses have a genome comprising two similar sized DNA components (DNA A and DNA B). The DNA A component encodes a replication-associated protein (Rep) 
that is essential for viral DNA replication, a replication enhancer protein (REn), the coat protein $(\mathrm{CP})$ and a transcription activator protein (TrAP) that controls late gene expression. The DNA B component encodes a nuclear shuttle protein (NSP) and a movement protein (MP), both of which are essential for systemic infection of plants (Hanley-Bowdoin et al., 1999; Gafni and Epel, 2002).

In contrast, some begomoviruses have only a single genomic component which resembles DNA A, such as isolates of Tomato yellow leaf curl virus (TYLCV), Tomato leaf curl virus (TLCV), Ageratum yellow vein virus (AYVV) and Cotton leaf curl virus (CLCuV) (Kheyr-Pour et al., 1991; Navot et al., 1991; Dry et al., 1993; Briddon et al., 2000).

C. grandis is a weed, belonging to the family Cucurbitaceae is distributed in tropical Asia, Africa and also commonly found in India, Pakistan, and Srilanka (Farrukh et al., 2008). In Southeast Asia, C. grandis is grown for its edible young shoots and fruits. Every part of this plant like leaves, fruits, stem and roots are valuable in medicine and various preparations have been mentioned in indigenous system of medicine for various skin diseases, bronchial catarrh, bronchitis and unani systems of medicine for ring worm, psoriasis, small pox, scabies (Perry, 1980). Infected plants were exhibiting multiple symptoms such as: leaf reduction, mosaic, chlorosis, curling on leaf and stem (Figure 1). In the present study an attempt were made to characterize the mix infection of the potyvirus and geminivirus infection in $C$. grandis and characterization of the viruses at molecular level.

\section{Materials and Methods}

For the investigation of mixed infection of the potyvirus and the geminivirus, the symptomatic leaf of Coccinia grandis was collected from the Barasat, West Bengal, India and stored in $-80{ }^{\circ} \mathrm{C}$ for further identification and characterization of the viruses.

For the detection of potyvirus in symptomatic $C$. grandis leaf tissues, we used serologicalbased diagnosis and RT-PCR. Virus accumulation was assessed by antigen coated plate ELISA (ACP-ELISA) according to the instruction of the manufacturer (Agdia, USA). Briefly, a fresh samples (100 mg) were ground in $1 \mathrm{ml}$ indirect sample extraction buffer (0.159 gm Na2CO3, 0.290 gm $\mathrm{NaHCO} 3$ and PVP 2gm, and $0.02 \mathrm{gm} \mathrm{NaN3}$, adjusted $\mathrm{pH}$ 9.6) and $100 \mu \mathrm{l}$ of the samples were used for the test. ELISA plates were coated with $100 \mu$ of plant extract for each well and incubated 1 hour at room temperature. The plant extracts were removed from the plate and washed with phosphatebuffered saline (PBS) containing $0.05 \%$ Tween 20 (PBST), pH 7.4, for seven times. The plate was then added detection antibody (1:200 with ECI buffer) for $2 \mathrm{hrs}$ at room temperature or overnight at $4{ }^{\circ} \mathrm{C}$, and then washed with PBST for eight times.

Next, the alkaline phosphatase-conjugated (Agdia, USA) was diluted at 1:200 in ECI buffer [0.2 gm BSA; 2 gm PVP;] and $100 \mu \mathrm{l}$ buffer was added in each well and incubated at room temperature for 1 hour. After the plate was washed with PBST, $100 \mu \mathrm{l}$ of $p$ nitrophenyl phosphate (pNPP) was added as substrate for alkaline phosphatase in dark condition and incubated at room temperature for $60 \mathrm{~min}$. Absorbance at A405 nm was measured with an ELISA plate reader. Experiments were done in triplicate. Samples with absorbance values greater than or equal to three times the average of the negative samples were considered positive in ELISA.

Total RNA was extracted from $100 \mathrm{mg}$ of Coccinia leaf tissue using the Trizol method 
and was used in RT-PCR for amplification of potyvirus. RT was performed with $50 \mathrm{ng}$ of total RNA mixed with oligodT primers and Super Reverse Transcriptase MuLV kit (Biobharti). Reaction mixtures were incubated at $42{ }^{\circ} \mathrm{C}$ for $50 \mathrm{~min}$ to synthesize the first strand cDNA, and then the reaction was inactivated by heating at $70{ }^{\circ} \mathrm{C}$ for $15 \mathrm{~min}$. RT products were heated at $94{ }^{\circ} \mathrm{C}$ for $2 \mathrm{~min}$ and amplification was performed with 35 cycles of $30 \mathrm{sec}$ for strand separation at 94 ${ }^{\circ} \mathrm{C}, 1 \mathrm{~min}$ for primer annealing at $50^{\circ} \mathrm{C}$ and 1 min for synthesis at $72{ }^{\circ} \mathrm{C}$, and $10 \mathrm{~min}$ at 72 ${ }^{\circ} \mathrm{C}$ for final extension using pair of potyvirus specific degenerate primers (MJ1 and MJ2) (Marie-Jeanne et al., 2000).

For the detection of geminivirus, two detection techniques were used: 1) PCR amplification of virus by using indigenously designed geminivirus specific primer pair and 2) using Southern blot analysis using biotinlabeled probes specific for geminivirus.

Total DNA was extracted from $C$. grandis leaf using our new modified CTAB method (Roy et al., 2017) and tested for the presence of geminiviruses by PCR using indigenously designed geminiviruses specific degenerate primer pair (Roy et al., 2015).

The PCR was performed under following condition: initial denaturation $95{ }^{\circ} \mathrm{C}$ for 5 min, following by 35 cycles of $94{ }^{\circ} \mathrm{C}$ for 30 sec, $48{ }^{\circ} \mathrm{C}$ for $45 \mathrm{sec}, 72{ }^{\circ} \mathrm{C}$ for $1 \mathrm{~min}$, and final extension at $72{ }^{\circ} \mathrm{C}$ for $7 \mathrm{~min}$. The expected fragment size of the amplicon was about $760 \mathrm{nt}$. The PCR products were eluted from $1 \%$ agarose using the gel extraction kit (XcelGen- Xcelris Genomics) and sent for sequencing.

For the Southern blot analysis, we designed a biotin labeled probe and used for the detection of the geminiviruses from the total sap of the infected plant samples. Briefly, about $5 \mu \mathrm{l}$ of freshly prepared sap was blotted on the nitro cellulose membrane and air dried the membrane properly. After that the membrane was UV-cross linked for 30 min under UVCross Linker (GeNei ${ }^{\mathrm{TM}}$ India). Prehybridization, hybridization and washing of membrane were done according to the southern blot analysis protocol using biotinlabeled probes (Weigel et al., 2015).

Both the sequences of PCR products were analyzed with available sequences obtained from the GenBank database using Multalin, BLASTn, and pairwise identity scores were calculated using SDTv1.2 (Sequences Demarcation Tool version 1.2). Phylogenetic tree was constructed using Vector NTI, BioEdit and Neighbor- joining analysis with Phylip programs.

\section{Results and Discussion}

During the survey, leaves of the $C$. grandis were found to be positive in ELISA against the potyvirus specific monoclonal antibody (Agdia, USA). The absorption readings more than three times of the control were considered as positive (Figure $2 \mathrm{a}$ ).

For the detection of potyvirus, the RT-PCR product with the expected size of $327 \mathrm{bp}$, encoding the core region of the coat protein gene (Figure 2b) was amplified. PCR product was eluted with the gel elution kite (XcelGen, Xcelris) and send for sequencing and the sequence was submitted in the GenBank database as accession number; LC194215.

During the detection of geminivirus a fragment of approx $\sim 760$ bp covering the parts of AV1, AC3 and AC2 genes, was amplified from $C$. grandis indicating the infection of the geminivirus in the plants (Figure 3a). PCR product was eluted with the gel elution kit as above and sent for sequencing and the sequence was submitted 
in the GenBank database as accession number; LC194216.

In Southern hybridization technique, symptomatic Coccinia plants hybridized with the probe, whereas samples extracted from non-symptomatic plants were negative in results (Figure 3b). Hybridization of geminivirus probe with the DNA samples on the nitrocellulose membrane indicates that these probes can also be used for the detection of begomoviruses. The strong signal showed that the virus titer in $C$. grandis is high.

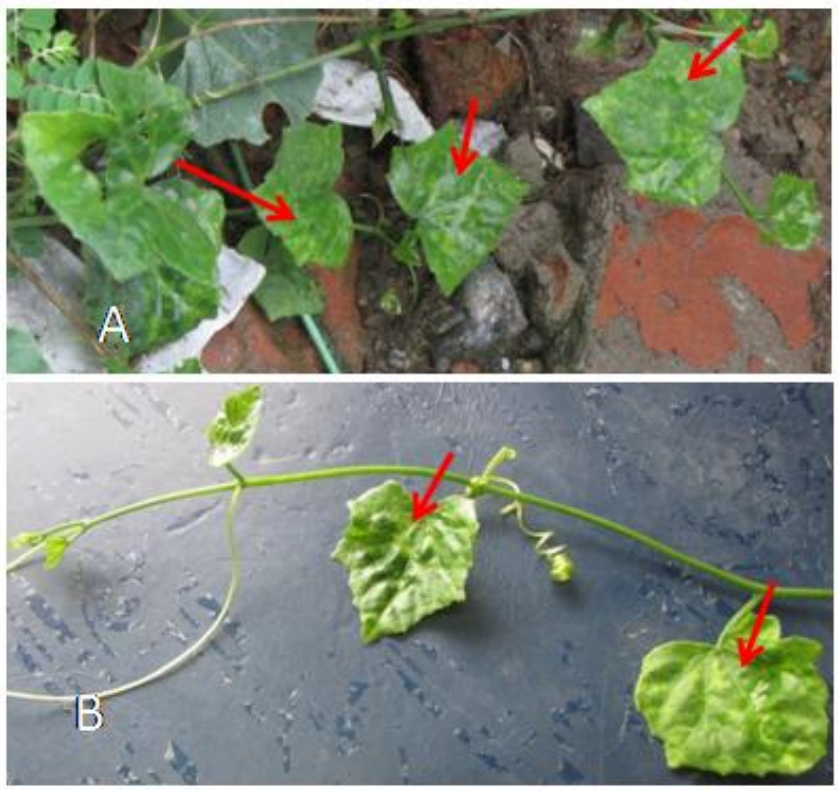

Figure 1: Symptomatic Coccinia grandisplants showing symptom. A: Symptomatic plants in filed. B: Symptomatic plants picture taken in lab. Amows indicating the symptomatic areas.

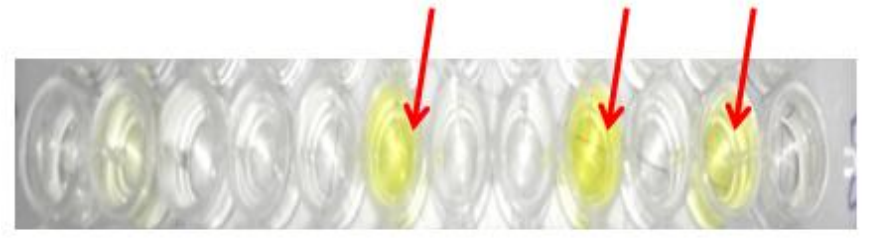

(a)

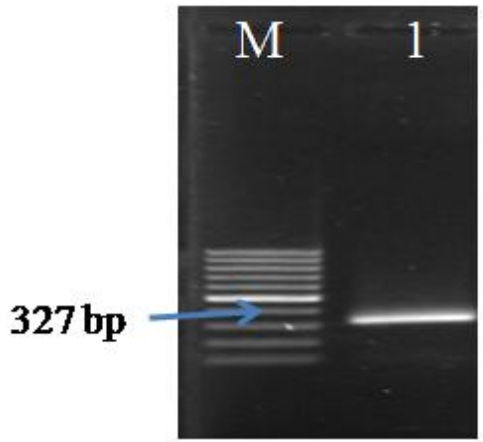

(b)

Figure 2: (a) Symptomatic plant sample indicating positive in ELISA by producing yellow color (Anows). (b) Agarose gel (1\%) showing the amplification part partial coat protein of Papaya ing spot vinus (327 bp) in C. grandis (bne 1), lane M: 100 bp ladder. 

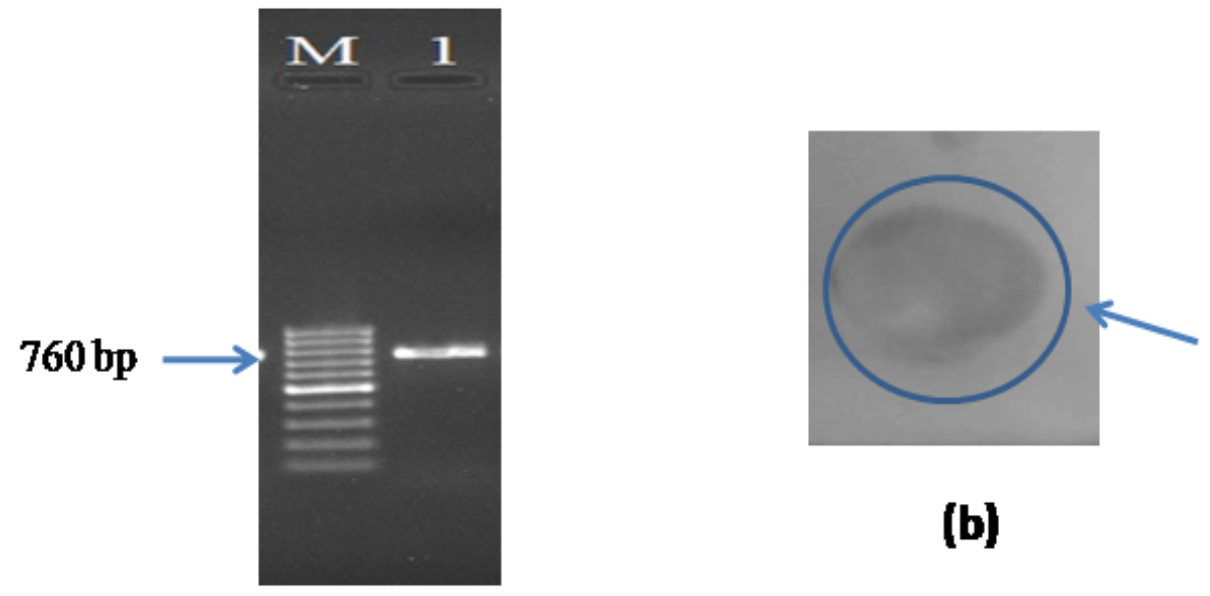

(b)

(a)

Figure 3: (a) Agarose gel (1\%) showing the amplification of Tomato leaf cur New Delhi vins partial AV1, AC3 and AC2 gene (760 bp) in C. grandis (lane 1), bne M: 100 bp ladder. (b) Southem blot hybridization for detection of TOLCNDV by using biotin probe.

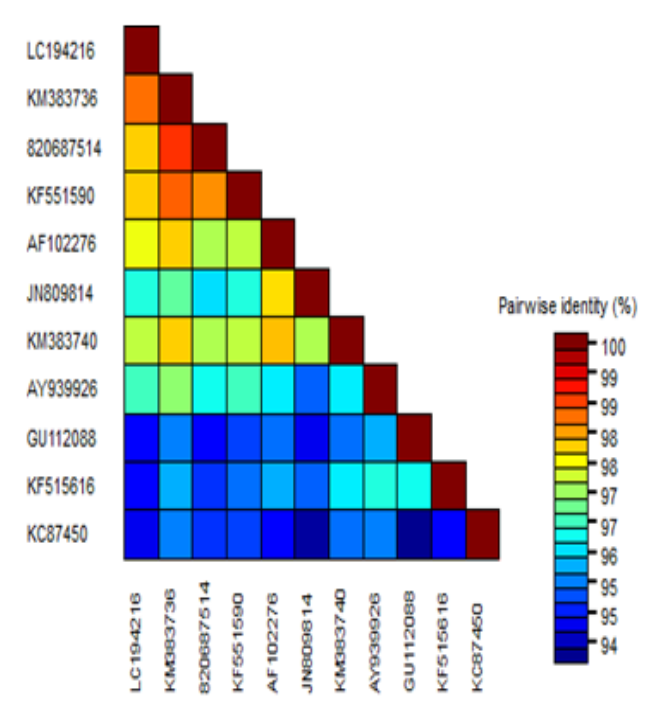

(a)

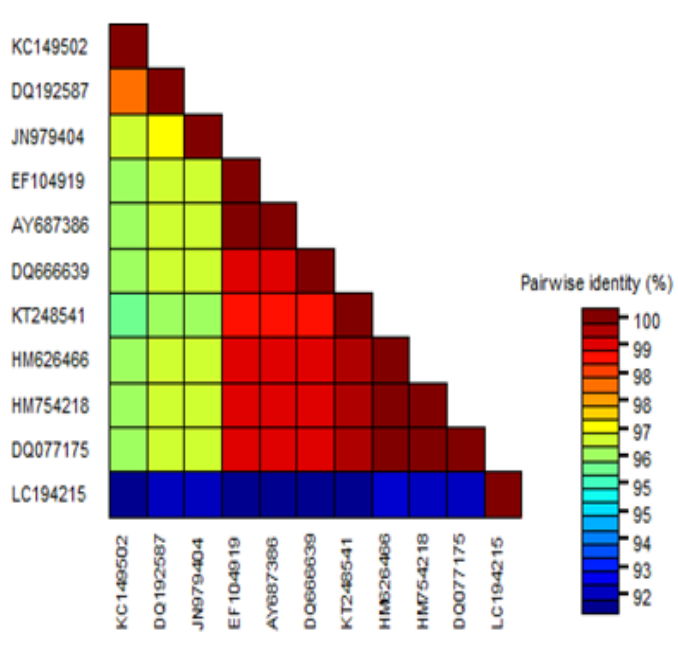

(b)

Figure 4: (a) Pairwise sequence data analysis of ToLCNDV-N with other closely related virus using Sequence Demarcation Tool Version 1.2 (SDTv1.2) software. (b) Pairwise sequence data analysis of PRSV with other Indian PRSV isolates using Sequence Demarcation Tool Version 1.2 (SDTv1.2)software. 

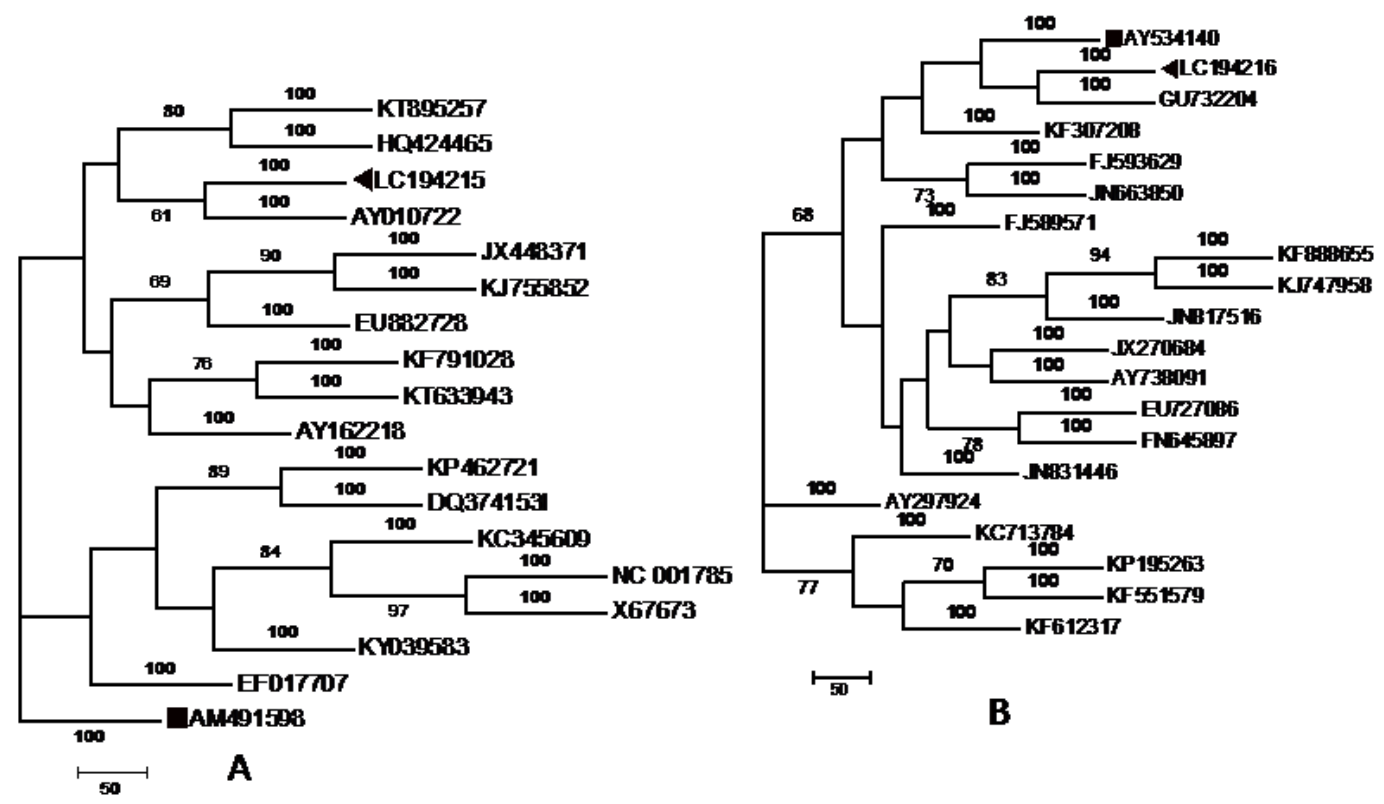

Figure. 5 NeighborJoining tree based on the sequence of PCR Products. (A): PRSV (acc. No. LC194215) isobted from C. grandis and other PRSV isolates available in the GenBank. Pepper mild mottle vinus partial coat protein (acc. No: AM491598) was used as an outgroup and marked with solid square and our sequence was marked with solid triangle. (B): Geminiviral sequence (acc. No. LC194216) of the virus isolated from C. grandis. and other begomovinus sequences available in GenBank. Banana bunchy top vinus coat protein (acc. No: AY534140) was used as an outgroup and marked with solid square. Our sequence was marked with solid triangle. The numbers below branches indicate bootstrap value percentages from 1000 replicates. Bootstrap value below $60 \%$ were note shown.

Both the sequences of PCR products were analyzed with available sequences obtained from the GenBank database using Multalin, BLASTn, and SDT. Pairwise identity scores were calculated using SDTv1.2 (Sequences Demarcation Tool version 1.2).

The amplicon of 327 bp RT-PCR product with potyviruses specific primers shared upto 92\% identity at the nucleotide level with other Indian Papaya ring spot virus isolate and amplicon of about 760 bp PCR product with geminivirus specific primers shared upto $98 \%$ sequence identity with the Tomato leaf curl New Delhi virus at nucleotide level (Figure 4a and $4 b$ ).

Phylogenetic trees were constructed using Vector NTI, Bio Edit and Neighbor- joining analysis with Phylip programs. Pepper mild mottle virus partial coat protein acc. No:
AM491598 was used as an out group and marked with Solid Square and for the analysis of geminivirus, Banana bunchy top virus acc. No: AY534140 was used as an out group and marked with Solid Square. Our both sequences were marked with solid triangles (Figure 5A and 5B).

To our knowledge, this is the first evidence of mixed infection of PRSV and ToLCNDV in $C$. grandis from India, although these two viruses were reported separately earlier (Nagendran et al., 2016, Noochoo et al., 2015). Many potyviruses and geminiviruses are emerging and re-emerging in the recent years and infecting different host and threatening the economically important crops which are susceptible for these viruses. Therefore, it is essential to further study the spread of the disease and characterize the viruses in details at molecular level and study 
the interaction between the host and vectors of the viruses are significant areas to focus in future research.

\section{Acknowledgement}

Authors would like to thank Department of Science and Technology, New Delhi for SERB Project Grant No. SR/FT/LS-165/2012 and financial assistant from University Grant Commission (UGC), New Delhi to Siriya Sultana, Senior Research Fellow (Maulana azad National Fellowship) in the form of fellowship is greatly acknowledged.

\section{References}

Berger, P.H., M.J. Adams, O.W. Barnett, A.A. Brunt, J. Hammond, J.H. Hill, R.L. Jordan, S. Kashiwazaki, E. Rybicki, N. Spence, C.M. Fauquet, M.A. Mayo, J. Maniloff, U. Desselberger and Ball L.A. 2005. Potyviridae. In Virus taxonomy. VIIIth Report of the International Committee on Taxonomy of Viruses. London: Elsevier/Academic Press; p. 819-841.

Briddon, R.W., S. Mansoor, I.D. Bedford, M.S. Pinner and Markham, P.G. 2000. Clones of cotton leaf curl geminivirus induce symptoms atypical of cotton leaf curl disease. Virus Genes 20: 19-26.

Dry, I.B., J.E. Rigden, L.R. Krake, P.M. Mullineaux and Rezaian, M.A. 1993. Nucleotide-sequence and genome organization of tomato leaf curl geminivirus. J. Gen. Virol. 74:147-151.

Farrukh, U., H. Shareef, S. Mahmud, S.A. Ali and Rizwani, G. H. 2008. Antibacterial activities of Coccinia grandis L. Pak. J. Bot. 40: 1259-1262.

Gafni, Y. and Epel, B.L. 2002. The role of host and viral proteins in intra- and inter-cellular trafficking of geminiviruses. Physio and Mol Plant Pathol 60: 231-241.
Gibbs, A. and Ohshima, K. 2010. Potyviruses and the digital revolution. Annu Rev Phytopathol. 48:205-223.

Hanley-Bowdoin, L., S.B. Settlage, B.M. Orozco, S. Nagar and Robertson, D. 1999. Geminviruses: models for plant DNA replication, transcription, and cell cycle regulation. Crit. Rev. Plant Sci., 18:71-106.

Kheyr-Pour, A., M. Bendahmane, V. Matzeit, G.P. Accotto, S. Crespi and Gronenborn, B. 1991. Tomato yellow leaf curl virus from Sardinia is a whitefly -transmitted monopartite geminivirus. Nucleic Acids Res. 19: 6763-6769.

Marie-Jeanne, V., R. Ioos, J. Peyre, B. Alliot and Signoret, P. 2000. Differentiation of Poaceae potyviruses by reverse transcription-polymerase chain reaction and restriction analysis. J. Phytopath. 148:141-51.

Martín, S. and Elena, S.F. 2009. Application of game theory to the interaction between plant viruses during mixed infections. J Gen Virol. 90:2815-20.

Nagendran, K., V.K. Satya, S. Mohankumar and Karthikeyan, G. 2016. Molecular characterization of a distinct bipartite Begomovirus species infecting ivy gourd (Coccinia grandis L.) in Tamil Nadu, India. Virus Genes. 52:146-151.

Navot, N., E. Pichersky, M. Zeidan, D. Zamir and Czosnek, H. 1991. Tomato yellow leaf curl virus a whitefly-transmitted geminivirus with a single genomic component. Virology 185:151-161.

Noochoo, S., W. Sritongchai and Chowpongpang, S. 2015.Production of Polyclonal Antibodies for Detection of Papaya ringspot virus (PRSV) in Ivy Gourd (Coccinia grandis (L.) Nat. Sci. 49: 350 - 360.

Perry, L.M. 1980. Medicinal Plants of East and South East Asia, Attributed properties and Uses, MIT Press, 
London.

Roy, B., B. Chakraborty, A. Mitra, S. Sultana and Sherpa, A.R. 2015. Natural occurrence of Bhendi yellow vein mosaic virus on Litsea spp. in India. New Dis. Rep. 31:7.

Roy, B. and Sherpa, A.R. 2017. Extraction of High Quality DNA from Mucilaginous Plants with a New Improved Method, Suitable for Detection of Geminiviruses and Downstream Applications. International J of Sci. 6: 121-124

Shukla, D.D., C.W. Ward, A.A. Brunt and Berger, P.H. 1998. Potyviridae family. In: Description of plant Viruses, No. 366. Association of Applied Biologists
(AAB); p. 12.

Verma, R., P. Gaikwad, D. Mungekar1, S. Tripathi1, V. Datar and Singh, J. 2014. First report of mixed infection of Papaya Ringspot Virus and Phytoplasma in Papaya in India. J Plant Pathol. 96: 431-439.

Ward, C.W. and Shukla, D.D., 1991. Taxonomy of Potyviruses-current problems and some solutions. 4 Intervirology 32:269-296.

Weigel, K., J.O. Pohl, C. Wege. And Jeske, H. 2015. A population genetics perspective on geminivirus infection. J Virol. 89:11926 -11934.

\section{How to cite this article:}

Siriya Sultana, Buddhadeb Roy and Ang Rinzing Sherpa. 2017. Mixed-Infection of Papaya Ring Spot Virus and Tomato Leaf Curl New Delhi Virus in Coccinia grandis in India. Int.J.Curr.Microbiol.App.Sci. 6(7): 1221-1228. doi: https://doi.org/10.20546/ijcmas.2017.607.147 